\title{
Cytokinesis Failure Leading to Chromosome Instability in v-Src-Induced Oncogenesis
}

\author{
Yuji Nakayama ${ }^{1, *}$, Shuhei Soeda ${ }^{2}$, Masayoshi Ikeuchi ${ }^{1}$, Keiko Kakae ${ }^{1}$ and Naoto Yamaguchi ${ }^{2}$ \\ 1 Department of Biochemistry \& Molecular Biology, Kyoto Pharmaceutical University, Kyoto 607-8414, Japan; \\ kd17001@poppy.kyoto-phu.ac.jp (M.I.); ky11084@poppy.kyoto-phu.ac.jp (K.K.) \\ 2 Laboratory of Molecular Cell Biology, Graduate School of Pharmaceutical Sciences, Chiba University, \\ Chiba 260-8675, Japan; soeda05@fc.ritsumei.ac.jp (S.S.); nyama@faculty.chiba-u.jp (N.Y.) \\ * Correspondence: nakayama@mb.kyoto-phu.ac.jp; Tel.: +81-75-595-4653; Fax: +81-75-595-4758
}

Academic Editors: Vassilis G. Gorgoulis, Athanassios Kotsinas, Alexandros G. Georgakilas, Ioannis Trougakos and Aristides Eliopoulos

Received: 22 February 2017; Accepted: 9 April 2017; Published: 12 April 2017

\begin{abstract}
Src, an oncogene found in Rous sarcoma virus, is a constitutively active variant of c-Src. Activation of Src is observed frequently in colorectal and breast cancers, and is critical in tumor progression through multiple processes. However, in some experimental conditions, v-Src causes growth suppression and apoptosis. In this review, we highlight recent progress in our understanding of cytokinesis failure and the attenuation of the tetraploidy checkpoint in v-Src-expressing cells. v-Src induces cell cycle changes-such as the accumulation of the $4 \mathrm{~N}$ cell population-and increases the number of binucleated cells, which is accompanied by an excess number of centrosomes. Time-lapse analysis of $\mathrm{v}$-Src-expressing cells showed that cytokinesis failure is caused by cleavage furrow regression. Microscopic analysis revealed that $\mathrm{v}$-Src induces delocalization of cytokinesis regulators including Aurora B and Mklp1. Tetraploid cell formation is one of the causes of chromosome instability; however, tetraploid cells can be eliminated at the tetraploidy checkpoint. Interestingly, $\mathrm{v}$-Src weakens the tetraploidy checkpoint by inhibiting the nuclear exclusion of the transcription coactivator YAP, which is downstream of the Hippo pathway and its nuclear exclusion is critical in the tetraploidy checkpoint. We also discuss the relationship between $\mathrm{v}$-Src-induced chromosome instability and growth suppression in v-Src-induced oncogenesis.
\end{abstract}

Keywords: v-Src; cytokinesis; tetraploidy checkpoint; YAP; chromosome instability

\section{Introduction}

$\mathrm{v}$-Src is an oncogene that was found in Rous sarcoma virus and its cellular counterpart is c-Src [1,2]. In v-Src, a C-terminal tyrosine residue that is phosphorylated by C-terminal Src kinase (Csk) and is responsible for the closed- and inactive-conformation is lost, resulting in the constitutive activation of $\mathrm{v}$-Src. Src activation is very common in colorectal and breast cancers and is frequently critical in tumor progression through multiple processes, including migration, invasion, anoikis resistance, disruption of cadherin-mediated cell-cell contacts, proliferation, and resistance to apoptosis [1,3]. However, in some experimental conditions, $\mathrm{v}-\mathrm{Src}$ causes growth suppression $[1,4]$.

Growth promoting factor-induced growth suppression has been reported. The addition of epidermal growth factor (EGF) to serum-free and serum-containing cell culture media results in a marked inhibition of cell proliferation in the A431 human epidermoid carcinoma cell line [5-7]. The growth of estrogen-independent breast cancer MDA-MB-468 cells-which overexpress the EGF receptor (EGFR) - is inhibited by EGF; this is accompanied by the increased expression of some genes, including c-myc [8]. Upon treatment with EGF, fibroblastic cells or mammary tumor cells overexpressing EGFR and ErbB2 undergo apoptosis in a p38-dependent manner [9]. Other pathways 
downstream of the EGFR are also involved in the suppression of cell proliferation. Ras provokes responses to cause cell cycle arrest or apoptosis, although Ras suppresses c-myc-induced apoptosis through the activation of the phosphatidylinositol 3-kinase (PI3K)/ Akt pathway [10,11]. Constitutively activated Raf-1, which is a proto-oncogene and a downstream kinase of Ras, increases apoptosis in breast cancer MCF-7 cells [12]. The deregulated expression of c-myc induces apoptosis, although it confers the ability to proliferate in low serum $[13,14]$. E2F-1 and v-Jun promote both cell cycle progression and apoptosis $[15,16]$. In addition, the adenovirus protein E1A stimulates transformed focus formation and induces apoptosis, which is inhibited by the E1B protein [17].

Similarly to these growth-promoting factors, v-Src has been reported to cause growth inhibition despite its oncogenic effects. The induced expression of the constitutively active mutant c-SrcY527F has a negative effect on the proliferation of human colorectal cancer HCT116 and SW480 cells in vitro and tumor growth in a xenograft model in vivo [18]. Cell cycle analysis showed the accumulation of cells in the G2 phase of the cell cycle with increased phosphorylation of Tyr15 in Cdk1 and decreased phosphorylation of Ser10 in histone H3 [18]. In Rat-1 fibroblast cells, v-Src does not accelerate the proliferation rate in spite of the decreased expression of the Cdk inhibitor p27 [19]. In carcinoma AA/C1/AB10 cells, an increase of EGFR expression enhances c-Src kinase activity, resulting in increased motility, but not growth stimulation [20]. Furthermore, when Ras and PI3K are inhibited simultaneously, v-Src induces apoptosis in a p53-independent manner [21,22].

Growth suppression and cell death following the hyper-induction of growth factor signaling are thought to be cellular responses to suppress the propagation of unfavorable genes, since activated Ras induces DNA double strand breaks, and other oncogenes, such as myc and E2F1, have similar effects [23,24]. If this is the case, it is thought that growth factor signaling requires further alterations of the gene profiles of primary cells to escape from growth factor-induced growth suppression. One way of altering gene profiles is via changes in gene expression, which is accomplished by gene usage at the transcriptional level, which is observed in v-Src-expressing cells [25]. Another way to alter gene profiles is genetic diversification through chromosome instability. Chromosome instability can be caused by the aberrant segregation of chromosomes during cell division. However, only a few reports have examined the effect of v-Src on genetic stability. In this review we describe our recent findings, including the effect of v-Src on cell proliferation, cytokinesis, and attenuation of the tetraploidy checkpoint, and then discuss the relationship between $\mathrm{v}$-Src-induced chromosome instability and growth suppression in v-Src-induced oncogenesis.

\section{2. v-Src Suppresses Cell Proliferation and Induces Tetraploidization}

We generated three cell lines derived from mouse fibroblast NIH3T3, human cervix HeLa S3, and human colorectal HCT116 cells-which can induce the expression of v-Src upon treatment with the tetracycline analog doxycycline (Dox) - to observe the effect of $\mathrm{v}$-Src on cell proliferation [4]. When these cells were treated with Dox, v-Src was expressed; phosphorylation of the tyrosine residues in a large number of proteins was enhanced. Cell-cell attachments were weakened, which was accompanied by the loss of E-cadherin staining from the plasma membrane, and the cells were round-shaped. These are the typical features of v-Src expression. v-Src caused growth suppression in these cells, and flow cytometry analysis revealed the alteration of cell cycle progression. While a low concentration of Dox caused the slight accumulation of cells with more than $4 \mathrm{~N}$ DNA, a high concentration of Dox caused the transient accumulation of $4 \mathrm{~N}$ cells and then an increase in the sub-G1 population, indicating the induction of apoptosis.

It is noteworthy to mention that the expression level of v-Src in these cells depends on the Dox concentration and the duration of induction. When these cells are treated with a high concentration of Dox, despite induction for only a short period, $\mathrm{v}$-Src is expressed at high levels and induces a variety of effects, including the detachment of the cells from the culture dish. This makes it difficult to perform observations under a microscope. Furthermore, it induces growth suppression and apoptosis as described above. In contrast, a low concentration of Dox induces moderate increases in protein-tyrosine 
phosphorylation and causes some phenotypes; however, it causes neither detachment of cells nor growth suppression. Thus, these cell lines are thought to be very useful for studying the effect of v-Src at different expression levels without detachment. Furthermore, it is thought that each phenotype caused by v-Src has its own threshold of tyrosine phosphorylation. We chose the concentration of Dox and duration of induction that resulted in less of an effect on both cell proliferation and attachment to the culture dish, but also made it possible to observe the cells under a microscope.

In order to elucidate how $4 \mathrm{~N}$ cells accumulate following $\mathrm{v}-\mathrm{Src}$ expression, the cells were treated with the low concentration of Dox for 6 days. Microscopic analysis showed the accumulation of binucleated cells, suggesting that the accumulation of $4 \mathrm{~N}$ cells is not attributed to G2-arrest. Taken together with the increase in the number of centrosomes, these binucleated cells are generated through cytokinesis failure. Time-lapse analysis of v-Src-expressing cells confirmed that cytokinesis failure is caused by the regression of the cleavage furrow, resulting in the accumulation of $4 \mathrm{~N}$ cells.

Src family kinases are known to regulate cell division. Upon mitotic entry, Cdk1 induces phosphorylation of the unique domain of Src family kinases, leading to up-regulation of their kinase activities [26-30]. Mitotic entry is inhibited by microinjection of anti-Src antibody into G2 cells [31], and inhibition of Src family kinases blocks mitotic progression in prophase [32]. Cytokinesis is also inhibited by microinjection of anti-Src antibody or Src homology 2 (SH2) domain of Src, or by treatment with the Src inhibitor PP2 [33-35]. These results suggest that Src family kinases are required for proper mitotic progression. Each member of the Src family kinases appears to have a distinct role in cell division. Fyn, a member of Src family kinases, participates in the assembly of mitotic spindle microtubules and accelerates mitotic progression [36]. c-Src promotes proper spindle orientation in early prometaphase [37]. Because kinase activities are tightly regulated in a spatiotemporal manner during cell division, we had expected that $\mathrm{v}-\mathrm{Src}$ - which is aberrantly and constitutively activated—gives rise to uncontrolled cell division including cytokinesis failure.

\section{3. v-Src-Induced Cytokinesis Failure Is Caused through Delocalization of Mitotic Regulators}

Cytokinesis is the final process that divides cell contents into 2 cells (see reviews, [38,39]). During this process, a signal is transferred from the central spindle to the equatorial cortex. Central spindle formation is regulated by the chromosomal passenger complex (CPC), which consists of Aurora B, INCENP, Survivin, and borealin, but also requires PRC1, KIF4, and Mklp1. Mklp1, a component of the centralspindlin complex, is phosphorylated at Ser708 by Aurora B and is thereby recruited to the spindle midzone. The CPC and centralspindlin complex play roles in contractile ring assembly at the equatorial cortex. After the constriction of the contractile ring, the cell is finally separated into two daughter cells through a final step called abscission, in which ESCRT-III proteins catalyze the scission of membrane necks. Abscission timing is regulated by Plk1 and Aurora B kinases, and Aurora $B$ prevents premature abscission if chromosome bridges are present in the intracellular bridges.

In order to explore the mechanism underlying v-Src-induced cytokinesis failure, we examined the localization of cytokinesis regulators and found the delocalization of the kinesin motor proteins Mklp1 and Mklp2, and the components of the CPC-Aurora B kinase and INCENP-from the anaphase midzone (Figure 1) [4]. Cleavage furrow ingression requires the localization of Mklp1; $\mathrm{v}$-Src-induced cytokinesis failure is caused by Mklp1 delocalization. Given that v-Src downregulates cell adhesion [4,40], and that cell adhesion interacts with cytokinesis [41,42], v-Src-induced cytokinesis failure would be caused by detachment of v-Src-expressing cells. We examined suspension cultures of HeLa S3 cells to exclude the possibility that the detachment of v-Src-expressing cells is involved in v-Src-induced cytokinesis failure. Similar to cells attached to culture dishes, Aurora B was localized to the anaphase midzone in the absence of $\mathrm{v}$-Src expression and delocalized upon $\mathrm{v}$-Src expression in suspension-cultured HeLa S3 cells, excluding the possibility that cytokinesis failure is caused by the loss of adhesion of v-Src-expressing cells.

How are cytokinesis regulators delocalized by v-Src? A plausible hypothesis is the inhibition of the kinesin-like motor protein Mklp2, which is responsible for the relocation of the CPC from 
the centromeres to the anaphase spindle midzone [43]. Knockdown of Mklp2 causes failure of abscission, generating binucleated cells [44]. In the absence of Mklp2, Mklp1 phosphorylation at Ser708, which is required for the recruitment of Mklp1 to the midzone, is lost [45]. This phosphorylation is catalyzed by Aurora B, and when Mklp2 is knocked down, Aurora B cannot relocate to the anaphase spindle midzone and remains with segregating chromosomes at anaphase [43]. Thus, Aurora B cannot phosphorylate Mklp1 at Ser708, resulting in the delocalization of Mklp1 and thereby causing cytokinesis failure. However, this hypothesis is unlikely to be true, since Aurora B never co-localizes with segregating chromosomes upon v-Src expression.
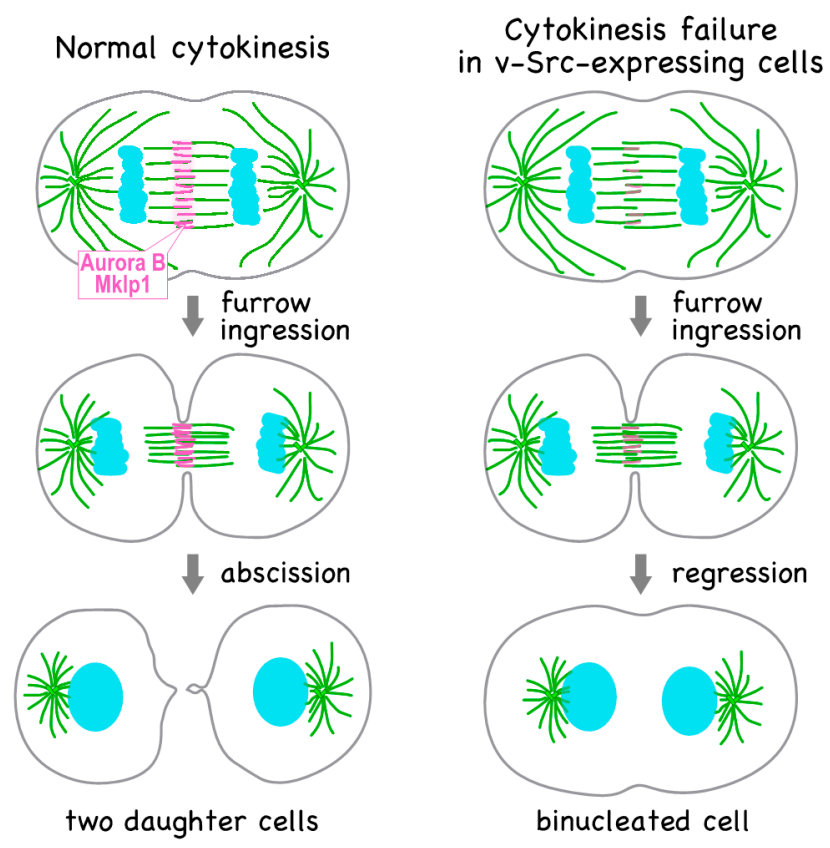

Figure 1. v-Src induces cytokinesis failure. The chromosomal passenger complex (CPC) and centralspindlin complex are localized at the spindle midzone; however, v-Src causes delocalization of the components of these complexes. As a result, cytokinesis fails due to regression of the cleavage furrow, resulting in the formation of binucleated cell.

Interestingly, the delocalization of Aurora B was observed after a 15-min incubation of v-Src-expressing cells with the Aurora B inhibitor ZM447439 [4]. This means that the kinase activity of Aurora B is required to maintain its localization to the anaphase spindle midzone, in agreement with a previous report [46]. When the cell cycle was synchronized by treatment with nocodazole, the auto-phosphorylation of Aurora B was not different between v-Src-expressing and v-Src-non-expressing cells. However, kinase activity should be evaluated in anaphase cells and not in nocodazole-synchronized cells. Considering that the duration of anaphase is generally short, it seems to be difficult to examine protein modifications at anaphase by western blotting because of the difficulty of synchronizing the cell cycle at anaphase. However, we developed a method to synchronize cells at anaphase by using a low concentration of nocodazole and blebbistatin and optimizing the period of treatment with the reagents, by which approximately $40 \%$ of cells were synchronized at anaphase [47]; nevertheless, it is still difficult to synchronize the cell cycle in v-Src-expressing cells due to the changes in the cell cycle $[4,18]$ and partial disruption of the spindle assembly checkpoint $[4]$. Thus, after optimization of the protocol for synchronizing v-Src-expressing cells, further studies including a search for v-Src substrates would help to understand the mechanism underlying the v-Src-induced delocalization of cytokinesis regulators. 


\section{4. v-Src Attenuates the Tetraploidy Checkpoint}

Although tetraploidy is one of the causes of chromosome instability through the increase in the number of centrosomes [48,49] and promotes tumorigenesis in p53-null cells [50], tetraploid cells can be removed by a mechanism called the tetraploidy checkpoint [51-53]. However, we observed a time-dependent increase in the number of binucleated cells upon the induced expression of v-Src in human colon carcinoma HCT116 and mouse fibroblast NIH3T3 cells, which is accompanied by the accumulation of the $4 \mathrm{~N}$ cell population on flow cytometry analysis. Furthermore, we also observed an increase in the number of cells having multipolar spindles with excess centrosomes. These results suggest that $\mathrm{v}$-Src causes chromosome instability through cytokinesis failure and the resulting tetraploidization. However, given that cell cycle progression is prevented in tetraploid cells by the tetraploidy checkpoint, tetraploid cells generated by v-Src expression should be arrested at the G1 phase with 4N DNA content. Thus, the increase in the number of cells with multipolar spindles raised the possibility that the tetraploidy checkpoint is attenuated in v-Src-expressing cells.

The Hippo pathway is reportedly activated in tetraploid cells; LATS kinases are activated, resulting in the inhibition of the transcriptional regulators YAP and TAZ and the stabilization of p53 (Figure 2) [53]. In this case, YAP is phosphorylated by LATS2 and excluded from the nucleus. In addition, LATS2 binds to and inhibits MDM2 - an E3 ubiquitin ligase for p53-leading to p53 stabilization [54]. We observed that the subcellular localization of YAP in NIH3T3 cells depended on cell density, suggesting that its subcellular localization is downstream of the Hippo pathway in NIH3T3 cells [4]. This subcellular localization was found to be partially regulated by Src kinase activity, since Src inhibition by the Src inhibitor PP2 led to the cytoplasmic localization of YAP, and v-Src expression led to the nuclear localization of YAP. When NIH3T3 cells were treated with cytochalasin B or the Plk1 inhibitor BI2536, the number of binucleated cells was increased through cytokinesis failure. In these binucleated cells, the cytoplasmic localization of YAP was promoted, suggesting activation of the Hippo pathway. However, v-Src expression led to the nuclear localization of YAP in most of the binucleated NIH3T3 cells. In agreement with these subcellular localizations, v-Src inhibited the phosphorylation of LATS kinases and YAP, indicating that v-Src may inhibit LATS kinases and thereby inhibits YAP phosphorylation, although the v-Src substrate responsible for this phenotype has not been determined. Therefore, v-Src may weaken the tetraploidy checkpoint by attenuating the Hippo pathway.

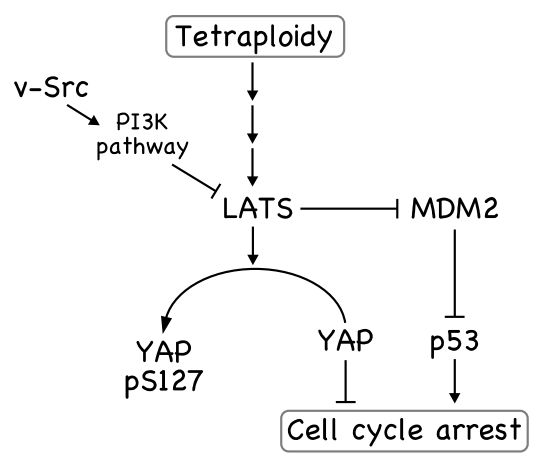

Figure 2. v-Src weakens the tetraploidy checkpoint. LATS kinases, which are activated in tetraploid cells, phosphorylate YAP, leading to exclusion of YAP from the nucleus. In addition, LATS activation results in stabilization of p53 through inhibition of MDM2. As a result, tetraploid cells are removed at this tetraploidy checkpoint. v-Src inhibits YAP phosphorylation by inhibiting LATS, possibly through activation of the PI3K pathway.

One possible mechanism underlying the v-Src-induced suppression of the Hippo pathway could be phosphorylation of YAP by v-Src. YAP was isolated initially as a Yes-associated protein, where YAP binds to the Src homology 3 (SH3) domain of Yes, a member of the Src-family kinases [55], in a manner 
that depends on Yes kinase activity [56]. YAP is phosphorylated at Tyr357 by Yes [57], resulting in the nuclear localization of YAP [58]. Abl tyrosine kinase also phosphorylates YAP at this site, leading to the stabilization of YAP [59]. However, we never observed an increase in the expression level of YAP upon v-Src expression. Thus, direct phosphorylation of YAP at Tyr357 by v-Src may not be responsible for the v-Src-induced nuclear localization of YAP in our experimental conditions. Another possibility is activation of PI3K by v-Src. The FAK-Src-PI3K pathway reportedly inhibits the Hippo pathway, leading to a decrease in YAP phosphorylation at Ser127 [60]. Since v-Src is also known as an activator of PI3K, v-Src may activate PI3K and reduce the activity of LATS kinases.

The tumor suppressor p53 also plays an important role in the suppression of the cell cycle in tetraploid cells (Figure 2) [54]. We also observed a decrease in p53 levels in v-Src-expressing cells [40]. p53 degradation is regulated by the E3 ubiquitin ligase MDM2 [61-64], which is inactivated by LATS2 [54]. Because we observed the v-Src-induced reduction of YAP phosphorylation at Ser127, a substrate of LATS kinases, the inactivation of LATS kinases could be the underlying mechanism; namely, inactivated LATS kinases cannot prevent MDM2-mediated p53 degradation, leading to a decrease in p53 levels. Src also reduces p53 levels in a different way; Src inactivates the phosphatase PP2A by phosphorylating Tyr307, leading to MDM2-mediated p53 degradation through an increase in MDM2 phosphorylation at Ser166, which enhances its interaction with p53 [65]. Furthermore, strong growth signals can overcome cell cycle arrest in tetraploid cells [53]. v-Src stimulates growth signals, such as ERK and Akt, contributing to the silencing of the tetraploidy checkpoint. Taken together, $\mathrm{v}$-Src may weaken the tetraploidy checkpoint through multiple pathways.

\section{5. v-Src Can Induce Chromosome Instability, Generating Genetic Diversity}

One of the causes of chromosome instability is the formation of multipolar spindles [66]. An excess number of centrosomes lead to the asymmetrical segregation of chromosomes through multipolar spindle formation and the following multipolar anaphase. However, an excess number of centrosomes tend to form bipolar spindles by centrosome clustering; that is, centrosomes gather into two poles after the formation of multipolar spindle intermediates [48]. These plausible bipolar spindles function incorrectly, since lagging chromosomes are observed frequently during anaphase [48]. For bipolar spindles with an excess number of centrosomes, merotelic kinetochore-microtubule attachment errors occur easily, resulting in lagging chromosomes [48,66-68]. Thus, dysregulation of the number of centrosomes results in chromosome instability.

$\mathrm{v}$-Src induces tetraploid cells through cytokinesis failure. Tetraploid cells have an excess number of centrosomes, which can form multipolar spindles. Even though pole clustering prevents cells from forming multipolar spindles, transient multipolar spindle intermediates favor the formation of merotelic attachments [48]. This can lead to the premature onset of anaphase with lagging chromosomes, resulting in the formation of a micronucleus [69]. Chromosomes in micronuclei undergo complex and localized genomic rearrangements through a process called chromothripsis, in which chromosomes are fragmented and re-ligated by non-homologous end joining [69-71]. Thus, $\mathrm{v}$-Src-induced cytokinesis failure is a trigger for $\mathrm{v}$-Src-induced genetic diversification.

We reported that non-membrane-bound Src-family kinases induce formation of chromosome bridges [72], and that $\mathrm{v}$-Src also induces them in a caffeine-dependent manner through induction of DNA damage [73]. Chromosome bridges result in the generation of daughter cells with different numbers of chromosomes and thus generate genetic diversity. Furthermore, cytokinesis in cells with chromosome bridges sometimes fails if the chromosome bridges are not resolved before abscission. Chromosome bridges activate the abscission checkpoint that prevents cells in the abscission phase from furrow regression [74]. However, given that the abscission checkpoint requires Aurora B kinase activity [75-77], v-Src may disrupt the abscission checkpoint and induce furrow regression of cells with chromosome bridges through delocalization of Aurora B from the midbody. Thus, v-Src can cause cytokinesis failure more frequently in chromosome bridge-containing cells than in cells without chromosome bridges. 
Aurora B regulates the appropriate binding of microtubules and kinetochores; monotelic and syntelic attachments are corrected at the spindle assembly checkpoint, which requires Aurora B kinase activity [78,79]. In addition, merotelic attachments are also corrected by a mechanism dependent on Aurora B and MCAK [80,81]. If the delocalization of Aurora B that was observed in v-Src-expressing anaphase cells [4] is caused before anaphase onset, it may give rise to erroneous chromosome segregation through inappropriate microtubule-kinetochore attachments. This can lead to further cytokinesis failure.

\section{Conclusions and Perspectives}

Genetic alteration through chromosome instability causes growth suppression. For example, aneuploid yeast cells show proliferative disadvantages, such as defects in cell cycle progression [82]. Mis-segregation of chromosomes in human diploid cells delays cell cycle progression, and the p53 pathway plays an important role in limiting the proliferation of aneuploid human cells [83]. Although the overexpression of Mad2, which is an essential component of the spindle assembly checkpoint, together with Kras ${ }^{\mathrm{G} 12 \mathrm{D}}$ delays Kras-driven tumor initiation, Mad2 overexpression facilitates oncogene-independent outgrowth and tumorigenesis in mice through chromosome instability [84-86]. This suggests that chromosome instability-driven genetic diversity can result in subclones and promote adaption for a strong selective pressure, such as the loss of growth signals by the withdrawal of oncogene and cell cycle arrest at checkpoints [87-89]. Although it has long been known that v-Src has oncogenic potential and accelerates malignant progression [1], it also causes growth suppression, as we observed in some cell lines [4]. We expect that the generation of genetic diversity is required for-v-Src-expressing cells in order to overcome $\mathrm{v}$-Src-induced growth suppression. Here, we propose a model for $\mathrm{v}$-Src-induced oncogenesis in addition to the canonical roles of v-Src (Figure 3). During v-Src-induced oncogenesis, v-Src induces tetraploidization through cytokinesis failure. Then, the activation of the tetraploidy checkpoint in tetraploid cells is suppressed by v-Src, leading to genetic diversification through chromosome instability. Among cells with broad genetic diversity, clones that adapt to growth-suppressive circumstances evolve and continue to proliferate or acquire the capacity to metastasize.
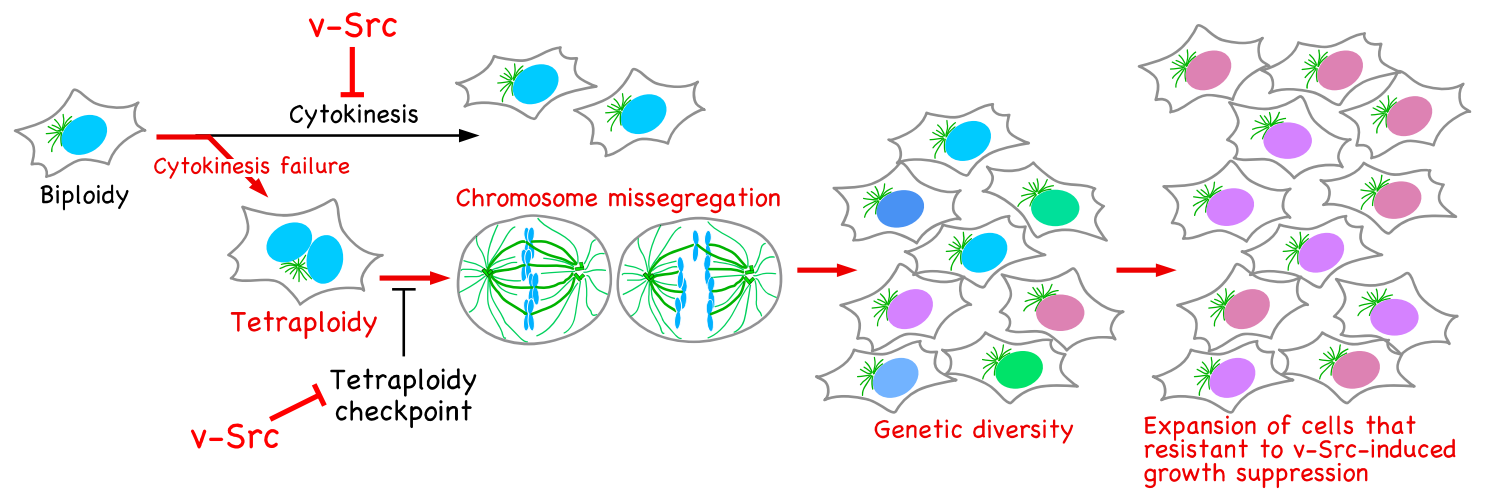

Figure 3. Genetic diversification in v-Src-expressing cells. v-Src induces tetraploidization through cytokinesis failure. The activation of the tetraploidy checkpoint in tetraploid cells is suppressed by $\mathrm{v}$-Src. Tetraploid cells give rise to chromosome mis-segregation, leading to genetic diversification. $\mathrm{v}$-Src causes growth suppression; however, among cells with broad genetic diversity, cells resistant to $\mathrm{v}$-Src-induced growth suppression can evolve and continue to proliferate.

Indeed, increases in Src activity are frequently observed in colon and breast cancers. In addition to the roles of Src activity in tumor development and malignancy through a variety of processes, we have shown that an increase in Src activity has the potential to affect genetic stability. We observed that overexpression of c-Src induces only slight increases in the number of binucleated cells [4], suggesting 
that further activation may be required for induction of cytokinesis failure. As our work was performed by using v-Src as a model for a constitutively active version of Src, further study is needed to determine the involvement of c-Src that is activated by a mutation in the C-terminal inhibitory tyrosine residue or by suppression of Csk activity. Csk is recruited to the vicinity of active Src in plasma membrane lipid rafts by binding to the transmembrane adaptor protein PAG/Cbp $[90,91]$. Thus, PAG/Cbp act as a negative regulator of Src. Src stimulates the PI3K and ERK pathways, leading to histone modifications that suppress PAG/Cbp synthesis at the transcriptional level, indicating the presence of a positive-feedback loop in oncogenic signaling [92]. It would be interesting to examine whether knockdown of PAG/Cbp expression causes chromosome instability.

$\mathrm{v}-\mathrm{Src}$ has the potential to induce epithelial-mesenchymal transition (EMT), which contributes to cancer progression [93-95]. Transcription factors including Snail, zinc-finger E-box-binding (ZEB) and basic helix-loop-helix (bHLH) drive EMT through repression of the epithelial marker genes and activation of the mesenchymal phenotype-associated genes [95]. The MEK/ERK pathway participates in EMT by increasing the expression of EMT transcription factors, and is also linked with the downregulation of E-cadherin in a manner independent of EMT transcription factors; downregulation of E-cadherin is a hallmark of EMT, which induces disassembly of adherens junctions. The MEK/ERK pathway causes overexpression of Cdc6, leading to repression of E-cadherin transcription [96]. Adherens junction maintenance requires the Rac activator Tiam1. During Src-induced disassembly of adherens junctions, Tiam1 is phosphorylated and degraded through activation of the MEK/ERK pathway [97]. As previously mentioned, v-Src stimulates the MEK/ERK pathway, suggesting that the MEK/ERK pathway is involved in the v-Src-induced EMT in both EMT transcription factor-dependent and -independent manners. As the effects of v-Src-induced genetic diversity on EMT have not yet been explored, further study is required to determine how chromosome instability caused by v-Src relates to cancer malignancy, including metastasis, in a mouse model.

Acknowledgments: This work was supported, in part, by Grants-in-Aid for Scientific Research from the Japan Society for the Promotion of Science (16K08253, 25460076) and a grant from the Promotion and Mutual Aid Corporation for Private Schools of Japan (Kyoto Pharmaceutical University and Chiba University).

Author Contributions: Yuji Nakayama and Naoto Yamaguchi wrote the paper. Yuji Nakayama, Shuhei Soeda, Masayoshi Ikeuchi, Keiko Kakae and Naoto Yamaguchi discussed and reviewed the manuscript.

Conflicts of Interest: The authors declare no conflict of interest.

\section{Abbreviations}

$\begin{array}{ll}\text { Csk } & \text { C-terminal Src kinase } \\ \text { EGF } & \text { epidermal growth factor } \\ \text { CPC } & \text { chromosomal passenger complex } \\ \text { SH2 } & \text { Src homology } 2 \\ \text { SH3 } & \text { Src homology } 3\end{array}$

\section{References}

1. Frame, M.C. Src in cancer: Deregulation and consequences for cell behaviour. Biochim. Biophys. Acta 2002, 1602, 114-130. [CrossRef]

2. Frame, M.C. Newest findings on the oldest oncogene; how activated src does it. J. Cell Sci. 2004, 117, 989-998. [CrossRef] [PubMed]

3. Summy, J.M.; Gallick, G.E. Src family kinases in tumor progression and metastasis. Cancer Metastasis Rev. 2003, 22, 337-358. [CrossRef] [PubMed]

4. Soeda, S.; Nakayama, Y.; Honda, T.; Aoki, A.; Tamura, N.; Abe, K.; Fukumoto, Y.; Yamaguchi, N. v-Src causes delocalization of Mklp1, Aurora B, and INCENP from the spindle midzone during cytokinesis failure. Exp. Cell Res. 2013, 319, 1382-1397. [CrossRef] [PubMed]

5. Barnes, D.W. Epidermal growth factor inhibits growth of A431 human epidermoid carcinoma in serum-free cell culture. J. Cell Biol. 1982, 93, 1-4. [CrossRef] [PubMed] 
6. Bravo, R. Epidermal growth factor inhibits the synthesis of the nuclear protein cyclin in A431 human carcinoma cells. Proc. Natl. Acad. Sci. USA 1984, 81, 4848-4850. [CrossRef] [PubMed]

7. Bravo, R.; Burckhardt, J.; Curran, T.; Müller, R. Stimulation and inhibition of growth by EGF in different A431 cell clones is accompanied by the rapid induction of c-fos and c-myc proto-oncogenes. EMBO J. 1985, 4, 1193-1197. [PubMed]

8. Armstrong, D.K.; Kaufmann, S.H.; Ottaviano, Y.L.; Furuya, Y.; Buckley, J.A.; Isaacs, J.T.; Davidson, N.E. Epidermal growth factor-mediated apoptosis of MDA-MB-468 human breast cancer cells. Cancer Res. 1994, 54, 5280-5283. [PubMed]

9. Tikhomirov, O.; Carpenter, G. Ligand-induced, p38-dependent Apoptosis in cells expressing high levels of epidermal growth factor receptor and ErbB-2. J. Biol. Chem. 2004, 279, 12988-12996. [CrossRef] [PubMed]

10. Kauffmann-Zeh, A.; Rodriguez-Viciana, P.; Ulrich, E.; Gilbert, C.; Coffer, P.; Downward, J.; Evan, G. Suppression of c-Myc-induced apoptosis by Ras signalling through PI(3)K and PKB. Nature 1997, 385, 544-548. [CrossRef] [PubMed]

11. Cox, A.D.; Der, C.J. The dark side of Ras: Regulation of apoptosis. Oncogene 2003, 22, 8999-9006. [CrossRef] [PubMed]

12. El-Ashry, D.; Miller, D.; Kharbanda, S.; Lippman, M.E.; Kern, F. Constitutive Raf-1 kinase activity in breast cancer cells induces both estrogen-independent growth and apoptosis. Oncogene 1997, 15, 423-435. [CrossRef] [PubMed]

13. Evan, G.I.; Wyllie, A.H.; Gilbert, C.S.; Littlewood, T.D.; Land, H.; Brooks, M.; Waters, C.M.; Penn, L.Z.; Hancock, D.C. Induction of apoptosis in fibroblasts by c-myc protein. Cell 1992, 69, 119-128. [CrossRef]

14. Pelengaris, S.; Rudolph, B.; Littlewood, T. Action of Myc in vivo-Proliferation and apoptosis. Curr. Opin. Genet. Dev. 2000, 10, 100-105. [CrossRef]

15. Clark, W.; Gillespie, D.A. Transformation by v-Jun prevents cell cycle exit and promotes apoptosis in the absence of serum growth factors. Cell Growth Differ. 1997, 8, 371-380. [PubMed]

16. Shan, B.; Lee, W.H. Deregulated expression of E2F-1 induces S-phase entry and leads to apoptosis. Mol. Cell. Biol. 1994, 14, 8166-8173. [CrossRef] [PubMed]

17. Rao, L.; Debbas, M.; Sabbatini, P.; Hockenbery, D.; Korsmeyer, S.; White, E. The adenovirus E1A proteins induce apoptosis, which is inhibited by the E1B 19-kDa and Bcl-2 proteins. Proc. Natl. Acad. Sci. USA 1992, 89, 7742-7746. [CrossRef] [PubMed]

18. Welman, A.; Cawthorne, C.; Ponce-Perez, L.; Barraclough, J.; Danson, S.; Murray, S.; Cummings, J.; Allen, T.D.; Dive, C. Increases in c-Src expression level and activity do not promote the growth of human colorectal carcinoma cells in vitro and in vivo. Neoplasia 2006, 8, 905-916. [CrossRef] [PubMed]

19. Johnson, D.; Frame, M.C.; Wyke, J.A. Expression of the v-Src oncoprotein in fibroblasts disrupts normal regulation of the CDK inhibitor p27 and inhibits quiescence. Oncogene 1998, 16, 2017-2028. [CrossRef] [PubMed]

20. Brunton, V.G.; Ozanne, B.W.; Paraskeva, C.; Frame, M.C. A role for epidermal growth factor receptor, c-Src and focal adhesion kinase in an in vitro model for the progression of colon cancer. Oncogene 1997, 14, 283-293. [CrossRef] [PubMed]

21. Odajima, J.; Matsumura, I.; Sonoyama, J.; Daino, H.; Kawasaki, A.; Tanaka, H.; Inohara, N.; Kitamura, T.; Downward, J.; Nakajima, K.; et al. Full oncogenic activities of v-Src are mediated by multiple signaling pathways: Ras as an essential mediator for cell survival. J. Biol. Chem. 2000, 275, 24096-24105. [CrossRef] [PubMed]

22. Webb, B.L.; Jimenez, E.; Martin, G.S. v-Src generates a p53-independent apoptotic signal. Mol. Cell. Biol. 2000, 20, 9271-9280. [CrossRef] [PubMed]

23. Halazonetis, T.; Gorgoulis, V.; Bartek, J. An Oncogene-Induced DNA Damage Model for Cancer Development. Science 2008, 319, 1352-1355. [CrossRef] [PubMed]

24. Carr, A.M.; Lambert, S. Replication stress-induced genome instability: The dark side of replication maintenance by homologous recombination. J. Mol. Biol. 2013, 425, 4733-4744. [CrossRef] [PubMed]

25. Maślikowski, B.M.; Néel, B.D.; Wu, Y.; Wang, L.; Rodrigues, N.A.; Gillet, G.; Bédard, P.-A. Cellular processes of $\mathrm{v}$-Src transformation revealed by gene profiling of primary cells-Implications for human cancer. BMC Cancer 2010, 10, 41. [CrossRef] [PubMed]

26. Chackalaparampil, I.; Shalloway, D. Altered phosphorylation and activation of pp60c-src during fibroblast mitosis. Cell 1988, 52, 801-810. [CrossRef] 
27. Morgan, D.O.; Kaplan, J.M.; Bishop, J.M.; Varmus, H.E. Mitosis-specific phosphorylation of p60c-src by p34cdc2-associated protein kinase. Cell 1989, 57, 775-786. [CrossRef]

28. Zheng, X.M.; Shalloway, D. Two mechanisms activate PTPalpha during mitosis. EMBO J. 2001, 20, 6037-6049. [CrossRef] [PubMed]

29. Kesavan, K.P.; Isaacson, C.C.; Ashendel, C.L.; Geahlen, R.L.; Harrison, M.L. Characterization of the in vivo sites of serine phosphorylation on Lck identifying serine 59 as a site of mitotic phosphorylation. J. Biol. Chem. 2002, 277, 14666-14673. [CrossRef] [PubMed]

30. Kuga, T.; Nakayama, Y.; Hoshino, M.; Higashiyama, Y.; Obata, Y.; Matsuda, D.; Kasahara, K.; Fukumoto, Y.; Yamaguchi, N. Differential mitotic activation of endogenous c-Src, c-Yes, and Lyn in HeLa cells. Arch. Biochem. Biophys. 2007, 466, 116-124. [CrossRef] [PubMed]

31. Roche, S.; Fumagalli, S.; Courtneidgett, S.A. Requirement for Src Family Protein Tyrosine Kinases in G2 for Fibroblast Cell Division. Science 1995, 269, 1567-1569. [CrossRef] [PubMed]

32. Moasser, M.M.; Srethapakdi, M.; Sachar, K.S.; Kraker, A.J.; Rosen, N. Inhibition of Src kinases by a selective tyrosine kinase inhibitor causes mitotic arrest. Cancer Res. 1999, 59, 6145-6152. [PubMed]

33. Ng, M.M.; Chang, F.; Burgess, D.R. Movement of membrane domains and requirement of membrane signaling molecules for cytokinesis. Dev. Cell 2005, 9, 781-790. [CrossRef] [PubMed]

34. Tominaga, T.; Sahai, E.; Chardin, P.; McCormick, F.; Courtneidge, S.A.; Alberts, A.S. Diaphanous-related formins bridge Rho GTPase and Src tyrosine kinase signaling. Mol. Cell 2000, 5, 13-25. [CrossRef]

35. Kasahara, K.; Nakayama, Y.; Nakazato, Y.; Ikeda, K.; Kuga, T.; Yamaguchi, N. Src signaling regulates completion of abscission in cytokinesis through ERK/MAPK activation at the midbody. J. Biol. Chem. 2007, 282, 5327-5339. [CrossRef] [PubMed]

36. Okamoto, M.; Nakayama, Y.; Kakihana, A.; Yuki, R.; Yamaguchi, N.; Yamaguchi, N. Fyn Accelerates M Phase Progression by Promoting the Assembly of Mitotic Spindle Microtubules. J. Cell. Biochem. 2016, 117, 894-903. [CrossRef] [PubMed]

37. Nakayama, Y.; Matsui, Y.; Takeda, Y.; Okamoto, M.; Abe, K.; Fukumoto, Y.; Yamaguchi, N. c-Src but not Fyn promotes proper spindle orientation in early prometaphase. J. Biol. Chem. 2012, 287, 24905-24915. [CrossRef] [PubMed]

38. Green, R.A.; Paluch, E.; Oegema, K. Cytokinesis in Animal Cells. Annu. Rev. Cell Dev. Biol. 2012, $28,29-58$. [CrossRef] [PubMed]

39. Fededa, J.P.; Gerlich, D.W. Molecular control of animal cell cytokinesis. Nat. Cell Biol. 2012, 14, 440-447. [CrossRef] [PubMed]

40. Kakae, K.; Ikeuchi, M.; Kuga, T.; Saito, Y.; Yamaguchi, N.; Nakayama, Y. v-Src-induced nuclear localization of YAP is involved in multipolar spindle formation in tetraploid cells. Cell. Signal. 2017, 30, 19-29. [CrossRef] [PubMed]

41. Kanada, M.; Nagasaki, A.; Uyeda, T.Q.P. Adhesion-dependent and Contractile Ring-independent Equatorial Furrowing during Cytokinesis in Mammalian Cells. Mol. Biol. Cell 2005, 16, 3865-3872. [CrossRef] [PubMed]

42. Shafikhani, S.H.; Mostov, K.; Engel, J. Focal adhesion components are essential for mammalian cell cytokinesis. Cell Cycle 2008, 7, 2868-2876. [CrossRef] [PubMed]

43. Gruneberg, U.; Neef, R.; Honda, R.; Nigg, E.A.; Barr, F.A. Relocation of Aurora B from centromeres to the central spindle at the metaphase to anaphase transition requires MKlp2. J. Cell Biol. 2004, 166, 167-172. [CrossRef] [PubMed]

44. Zhu, C.; Zhao, J.; Bibikova, M.; Leverson, J.D.; Bossy-wetzel, E.; Fan, J.; Abraham, R.T.; Jiang, W.; Jolla, L.; Diego, S.; et al. Functional Analysis of Human Microtubule-based Motor Proteins, the Kinesins and Dyneins, in Mitosis/Cytokinesis Using RNA Interference. Mol. Biol. Cell 2005, 16, 3187-3199. [CrossRef] [PubMed]

45. Douglas, M.E.; Davies, T.; Joseph, N.; Mishima, M. Aurora B and 14-3-3 coordinately regulate clustering of centralspindlin during cytokinesis. Curr. Biol. 2010, 20, 927-933. [CrossRef] [PubMed]

46. Murata-Hori, M.; Tatsuka, M.; Wang, Y.L. Probing the dynamics and functions of aurora B kinase in living cells during mitosis and cytokinesis. Mol. Biol. Cell 2002, 13, 1099-1108. [CrossRef] [PubMed]

47. Matsui, Y.; Nakayama, Y.; Okamoto, M.; Fukumoto, Y.; Yamaguchi, N. Enrichment of cell populations in metaphase, anaphase, and telophase by synchronization using nocodazole and blebbistatin: A novel method suitable for examining dynamic changes in proteins during mitotic progression. Eur. J. Cell Biol. 2012, 91, 413-419. [CrossRef] [PubMed] 
48. Ganem, N.J.; Godinho, S.A.; Pellman, D. A mechanism linking extra centrosomes to chromosomal instability. Nature 2009, 460, 278-282. [CrossRef] [PubMed]

49. Ganem, N.J.; Storchova, Z.; Pellman, D. Tetraploidy, aneuploidy and cancer. Curr. Opin. Genet. Dev. 2007, 17, 157-162. [CrossRef] [PubMed]

50. Fujiwara, T.; Bandi, M.; Nitta, M.; Ivanova, E.V.; Bronson, R.T.; Pellman, D. Cytokinesis failure generating tetraploids promotes tumorigenesis in p53-null cells. Nature 2005, 437, 1043-1047. [CrossRef] [PubMed]

51. Margolis, R.L.; Lohez, O.D.; Andreassen, P.R. G1 tetraploidy checkpoint and the suppression of tumorigenesis. J. Cell. Biochem. 2003, 88, 673-683. [CrossRef] [PubMed]

52. Bolgioni, A.F.; Ganem, N.J. The interplay between centrosomes and the Hippo tumor suppressor pathway. Chromosom. Res. 2016, 24, 93-104. [CrossRef] [PubMed]

53. Ganem, N.J.; Cornils, H.; Chiu, S.-Y.; O’Rourke, K.P.; Arnaud, J.; Yimlamai, D.; Théry, M.; Camargo, F.D.; Pellman, D. Cytokinesis Failure Triggers Hippo Tumor Suppressor Pathway Activation. Cell 2014, 158, 833-848. [CrossRef] [PubMed]

54. Aylon, Y.; Michael, D.; Shmueli, A.; Yabuta, N.; Nojima, H.; Oren, M. A positive feedback loop between the p53 and Lats2 tumor suppressors prevents tetraploidization. Genes Dev. 2006, 20, 2687-2700. [CrossRef] [PubMed]

55. Sudol, M. Yes-associated protein (YAP65) is a proline-rich phosphoprotein that binds to the SH3 domain of the Yes proto-oncogene product. Oncogene 1994, 9, 2145-2152. [PubMed]

56. Tamm, C.; Böwer, N.; Annerén, C. Regulation of mouse embryonic stem cell self-renewal by a Yes-YAPTEAD2 signaling pathway downstream of LIF. J. Cell Sci. 2011, 124, 1136-1144. [CrossRef] [PubMed]

57. Rosenbluh, J.; Nijhawan, D.; Cox, A.G.; Li, X.; Neal, J.T.; Schafer, E.J.; Zack, T.I.; Wang, X.; Tsherniak, A.; Schinzel, A.C.; et al. $\beta$-Catenin-driven cancers require a YAP1 transcriptional complex for survival and tumorigenesis. Cell 2012, 151, 1457-1473. [CrossRef] [PubMed]

58. Taniguchi, K.; Wu, L.-W.; Grivennikov, S.I.; de Jong, P.R.; Lian, I.; Yu, F.-X.; Wang, K.; Ho, S.B.; Boland, B.S.; Chang, J.T.; et al. A gp130-Src-YAP module links inflammation to epithelial regeneration. Nature 2015, 519, 57-62. [CrossRef] [PubMed]

59. Levy, D.; Adamovich, Y.; Reuven, N.; Shaul, Y. Yap1 Phosphorylation by c-Abl Is a Critical Step in Selective Activation of Proapoptotic Genes in Response to DNA Damage. Mol. Cell 2008, 29, 350-361. [CrossRef] [PubMed]

60. Kim, N.-G.; Gumbiner, B.M. Adhesion to fibronectin regulates Hippo signaling via the FAK-Src-PI3K pathway. J. Cell Biol. 2015, 210, 503-515. [CrossRef] [PubMed]

61. Honda, R.; Tanaka, H.; Yasuda, H. Oncoprotein MDM2 is a ubiquitin ligase E3 for tumor suppressor p53. FEBS Lett. 1997, 420, 25-27. [CrossRef]

62. Böttger, A.; Böttger, V.; Sparks, A.; Liu, W.L.; Howard, S.F.; Lane, D.P. Design of a synthetic Mdm2-binding mini protein that activates the p53 response in vivo. Curr. Biol. 1997, 7, 860-869. [CrossRef]

63. Haupt, Y.; Maya, R.; Kazaz, A.; Oren, M. Mdm2 promotes the rapid degradation of p53. Nature 1997, 387, 296-299. [CrossRef] [PubMed]

64. Kubbutat, M.H.G.; Jones, S.N.; Vousden, K.H. Regulation of p53 stability by Mdm2. Nature 1997, 387, $299-303$. [CrossRef] [PubMed]

65. Yu, Y.; Huang, H.; Li, J.; Zhang, J.; Gao, J.; Lu, B.; Huang, C. GADD45ß mediates p53 protein degradation via Src/PP2A/MDM2 pathway upon arsenite treatment. Cell Death Dis. 2013, 4, e637. [CrossRef] [PubMed]

66. Holland, A.J.; Cleveland, D.W. Boveri revisited: Chromosomal instability, aneuploidy and tumorigenesis. Nat. Rev. Mol. Cell Biol. 2009, 10, 478-487. [CrossRef] [PubMed]

67. Cosenza, M.R.; Krämer, A. Centrosome amplification, chromosomal instability and cancer: Mechanistic, clinical and therapeutic issues. Chromosom. Res. 2016, 24, 105-126. [CrossRef] [PubMed]

68. Meraldi, P. Centrosomes in spindle organization and chromosome segregation: A mechanistic view. Chromosom. Res. 2016, 24, 19-34. [CrossRef] [PubMed]

69. Crasta, K.; Ganem, N.J.; Dagher, R.; Lantermann, A.B.; Ivanova, E.V.; Pan, Y.; Nezi, L.; Protopopov, A.; Chowdhury, D.; Pellman, D. DNA breaks and chromosome pulverization from errors in mitosis. Nature 2012, 482, 53-58. [CrossRef] [PubMed]

70. Zhang, C.-Z.; Spektor, A.; Cornils, H.; Francis, J.M.; Jackson, E.K.; Liu, S.; Meyerson, M.; Pellman, D. Chromothripsis from DNA damage in micronuclei. Nature 2015, 522, 179-184. [CrossRef] [PubMed] 
71. Ly, P.; Teitz, L.S.; Kim, D.H.; Shoshani, O.; Skaletsky, H.; Fachinetti, D.; Page, D.C.; Cleveland, D.W. Selective $\mathrm{Y}$ centromere inactivation triggers chromosome shattering in micronuclei and repair by non-homologous end joining. Nat. Cell Biol. 2017, 19, 68-75. [CrossRef] [PubMed]

72. Honda, T.; Soeda, S.; Tsuda, K.; Yamaguchi, C.; Aoyama, K.; Morinaga, T.; Yuki, R.; Nakayama, Y.; Yamaguchi, N.; Yamaguchi, N. Protective role for lipid modifications of Src-family kinases against chromosome missegregation. Sci. Rep. 2016, 6, 38751. [CrossRef] [PubMed]

73. Ikeuchi, M.; Fukumoto, Y.; Honda, T.; Kuga, T.; Saito, Y.; Yamaguchi, N.; Nakayama, Y. v-Src Causes Chromosome Bridges in a Caffeine-Sensitive Manner by Generating DNA Damage. Int. J. Mol. Sci. 2016, 17, 871. [CrossRef] [PubMed]

74. Norden, C.; Mendoza, M.; Dobbelaere, J.; Kotwaliwale, C.V.; Biggins, S.; Barral, Y. The NoCut pathway links completion of cytokinesis to spindle midzone function to prevent chromosome breakage. Cell 2006, 125, 85-98. [CrossRef] [PubMed]

75. Thoresen, S.B.; Campsteijn, C.; Vietri, M.; Schink, K.O.; Liestøl, K.; Andersen, J.S.; Raiborg, C.; Stenmark, H. ANCHR mediates Aurora-B-dependent abscission checkpoint control through retention of VPS4. Nat. Cell Biol. 2014, 16, 550-560. [CrossRef] [PubMed]

76. Steigemann, P.; Wurzenberger, C.; Schmitz, M.H.; Held, M.; Guizetti, J.; Maar, S.; Gerlich, D.W. Aurora B-mediated abscission checkpoint protects against tetraploidization. Cell 2009, 136, 473-484. [CrossRef] [PubMed]

77. Carlton, J.G.; Caballe, A.; Agromayor, M.; Kloc, M.; Martin-Serrano, J. ESCRT-III Governs the Aurora B-Mediated Abscission Checkpoint Through CHMP4C. Science 2012, 336, 220-225. [CrossRef] [PubMed]

78. Sarangapani, K.K.; Asbury, C.L. Catch and release: How do kinetochores hook the right microtubules during mitosis? Trends Genet. 2014, 30, 150-159. [CrossRef] [PubMed]

79. Walczak, C.E.; Cai, S.; Khodjakov, A. Mechanisms of chromosome behaviour during mitosis. Nat. Rev. Mol. Cell Biol. 2010, 11, 91-102. [CrossRef] [PubMed]

80. Cimini, D.; Wan, X.; Hirel, C.B.; Salmon, E.D. Aurora Kinase Promotes Turnover of Kinetochore Microtubules to Reduce Chromosome Segregation Errors. Curr. Biol. 2006, 16, 1711-1718. [CrossRef] [PubMed]

81. Knowlton, A.L.; Lan, W.; Stukenberg, P.T. Aurora B Is Enriched at Merotelic Attachment Sites, Where It Regulates MCAK. Curr. Biol. 2006, 16, 1705-1710. [CrossRef] [PubMed]

82. Torres, E.M.; Sokolsky, T.; Tucker, C.M.; Chan, L.Y.; Boselli, M.; Dunham, M.J.; Amon, A. Effects of aneuploidy on cellular physiology and cell division in haploid yeast. Science 2007, 317, 916-924. [CrossRef] [PubMed]

83. Thompson, S.L.; Compton, D.A. Proliferation of aneuploid human cells is limited by a p53-dependent mechanism. J. Cell Biol. 2010, 188, 369-381. [CrossRef] [PubMed]

84. Sotillo, R.; Hernando, E.; Díaz-Rodríguez, E.; Teruya-Feldstein, J.; Cordón-Cardo, C.; Lowe, S.W.; Benezra, R. Mad2 Overexpression Promotes Aneuploidy and Tumorigenesis in Mice. Cancer Cell 2007, 11, 9-23. [CrossRef] [PubMed]

85. Rowald, K.; Mantovan, M.; Passos, J.; Buccitelli, C.; Mardin, B.R.; Korbel, J.O.; Jechlinger, M.; Sotillo, R. Negative Selection and Chromosome Instability Induced by Mad2 Overexpression Delay Breast Cancer but Facilitate Oncogene-Independent Outgrowth. Cell Rep. 2016, 15, 2679-2691. [CrossRef] [PubMed]

86. Sotillo, R.; Schvartzman, J.M.; Socci, N.D.; Benezra, R. Mad2-induced chromosome instability leads to lung tumour relapse after oncogene withdrawal. Nature 2010, 464, 436-440. [CrossRef] [PubMed]

87. Greaves, M.; Maley, C.C. Clonal evolution in cancer. Nature 2012, 481, 306-313. [CrossRef] [PubMed]

88. Chen, G.; Mulla, W.A.; Kucharavy, A.; Tsai, H.J.; Rubinstein, B.; Conkright, J.; McCroskey, S.; Bradford, W.D.; Weems, L.; Haug, J.S.; et al. Targeting the adaptability of heterogeneous aneuploids. Cell 2015, 160, 771-784. [CrossRef] [PubMed]

89. Endesfelder, D.; Burrell, R.A.; Kanu, N.; McGranahan, N.; Howell, M.; Parker, P.J.; Downward, J.; Swanton, C.; Kschischo, M. Chromosomal instability selects gene copy-number variants encoding core regulators of proliferation in ER+ Breast cancer. Cancer Res. 2014, 74, 4853-4863. [CrossRef] [PubMed]

90. Brdika, T.; Pavlistova, D.; Albrecht, L.; Bruyns, E.; Schraven, B. Phosphoprotein Associated with Glycosphingolipid-enriched Microdomains (PAG), a Novel Ubiquitously Expressed Transmembrane Adaptor Protein, Binds the Protein Tyrosine Kinase Csk and Is Involved in Regulation of T Cell Activation. J. Exp. Med. 2000, 191, 1591-1604. [CrossRef] 
91. Tarakhovsky, A.; Okada, M.; Kawabuchi, M.; Satomi, Y.; Takao, T.; Shimonishi, Y.; Nada, S.; Nagai, K. Transmembrane phosphoprotein Cbp regulates the activities of Src-familytyrosine kinases. Nature 2000, 404, 999-1003. [CrossRef] [PubMed]

92. Hrdinka, M.; Horejsi, V. PAG—A multipurpose transmembrane adaptor protein. Oncogene 2014, 33, 4881-4892. [CrossRef] [PubMed]

93. Shimizu, Y.; Yamamichi, N.; Saitoh, K.; Watanabe, A.; Ito, T.; Yamamichi-Nishina, M.; Mizutani, M.; Yahagi, N.; Suzuki, T.; Sasakawa, C.; et al. Kinetics of v-Src-induced epithelial-mesenchymal transition in developing glandular stomach. Oncogene 2003, 22, 884-893. [CrossRef] [PubMed]

94. Guarino, M. Src signaling in cancer invasion. J. Cell. Physiol. 2010, 223, 14-26. [CrossRef] [PubMed]

95. Lamouille, S.; Xu, J.; Derynck, R. Molecular mechanisms of epithelial-mesenchymal transition. Nat. Rev. Mol. Cell Biol. 2014, 15, 178-196. [CrossRef] [PubMed]

96. Sideridou, M.; Zakopoulou, R.; Evangelou, K.; Liontos, M.; Kotsinas, A.; Rampakakis, E.; Gagos, S.; Kahata, K.; Grabusic, K.; Gkouskou, K.; et al. Cdc6 expression represses E-cadherin transcription and activates adjacent replication origins. J. Cell Biol. 2011, 195, 1123-1140. [CrossRef] [PubMed]

97. Woodcock, S.A.; Rooney, C.; Liontos, M.; Connolly, Y.; Zoumpourlis, V.; Whetton, A.D.; Gorgoulis, V.G.; Malliri, A. Src-Induced Disassembly of Adherens Junctions Requires Localized Phosphorylation and Degradation of the Rac Activator Tiam1. Mol. Cell 2009, 33, 639-653. [CrossRef] [PubMed]

(C) 2017 by the authors. Licensee MDPI, Basel, Switzerland. This article is an open access article distributed under the terms and conditions of the Creative Commons Attribution (CC BY) license (http:/ / creativecommons.org/licenses/by/4.0/). 